\title{
Population Size, Plant Occupancy and Threats to Acavus in Three Selected Homegardens in Kandy District, Sri Lanka
}

\author{
Bandara A.M.R.S.*, Ranawana K.B. and Weerakoon B. \\ Department of Zoology, Faculty of Science, University of Peradeniya, Peradeniya, Sri Lanka \\ *saumyasnp@gmail.com
}

\begin{abstract}
Acavus is an endemic genus of arboreal land snails, widely distributed in south west wet zone of Sri Lanka. Acavus consist of three species, Acavus haemastoma, Acavus superbus and Acavus phoenix with two subspecies Acavus phoenix phoenix and Acavus phoenix custaneus. Although Acavus is an endemic Gondwanan relict there are only few studies carried out on these snails, especially focusing homegardens. Homegardens serve as islands of habitats maintaining a considerable portion of Acavus. The objectives of the study are to estimate the population size of Acavus, to study the tree species commonly occupied by Acavus and to identify the threats to Acavus in homegardens in Kandy district. Study was carried out in three homegardens (each with about 60 perches) in Kahalla, Pilimathalawa and Gampola for six months from February to July 2013. All the sites harboured Acavus phoenix custaneus. Each site was visited twice a month and total count of Acavus and tree species they occupied were recorded. Threats to Acavus also observed in the field. Sites that were studied showed basic characters of Kandyan homegardens. According to the results, population sizes of Acavus of the sites are as follows, Kahalla 181, Pilimathalawa 40 and Gampola 117. Of the Acavus observed highest percentages were observed associated with following tree species, Areca catechu (24.29\%), Artocarpus heterophyllus (15.91\%), Cocos nucifera (12.78\%), Michelia champaca (7.78\%), Persea Americana (5.35\%), Musa spp. (3.31\%), Coffea arabica (2.87\%), Gliricidia sepium (2.57\%), Caryota urens (2.52) and Artocarpus altilis (1.92\%). Rest of the Acavus observed was distributed in a variety of other tree and shrub species. In homegardens Acavus is threatened mainly by greater coucal (Centropus sinensis), occasionally by toque monkey (Macaca sinica), shrinking of homegardens (as they pass from generation to generation) and unawareness of public. It is clear that the presence of certain tree and shrub species supports the survival of Acavus in homegardens and sustainable use of such flora will help to maintain healthy Acavus populations.
\end{abstract}

Keywords: Population size, Homegarden, Endemic, Relict 